日本臨床麻酔学会第 40 回大会シンポジウム 日臨麻会誌 Vol.41 No.7, 614 621, 2021

令和時代の臨床研究デザイン Clinical study designs and methods in the era of Reiwa

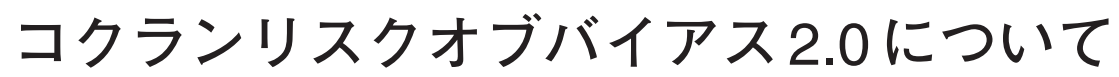

田中 優*

[要旨] コクランリスクオブバイアスはランダム化比較試験のバイアスを評価するのに広く使われ てきた. 2018 年に改訂版であるコクランリスクオブバイアス2.O(RoB2.O)が発表された. ドメ インは 5つで, (1)無作為化の過程から生じるバイアス, (2)意図した介入からの逸脱によるバイア ス, (3) 転帰データの欠落によるバイアス, (4)結果の測定におけるバイアス, (5) 報告された結果の 選択におけるバイアスである. ドメインの各領域内にシグナリング質問を含めることがRoB2の 重要な特徵で, バイアスのリスク評価に関連する情報を引き出すことを目的としている. また研究 全体のバイアスのリスクの程度も判定できる.

キーワード : コクランリスクオブバイアス2.0, シグナリングクエスション, ドメイン

\section{Iリスクオブバイアスの概要}

コクランは1992年に，イギリスの国民保健サー ビス (NHS) による根拠に基づく医療政策と実践, またその定量的な評価の一環として活動を開始した グローバルな非営利団体である。コクランは健康に 関してょり適切な意思決定がなされるためにあり， コクランのエビデンス(コクランレビュー)が世界中 で健康上の意思決定の核となることを目標としてい る、コクランのレビューは図1のプロセスで作成さ れる。

コクランレビューのような系統的レビューは採用 された論文の質によりその質が決定するため採用論 文の質評価が重要になり，それ故リスクオブバイア スツールによる論文評価が重要になる。

\section{II リスクオブバイアスの改訂}

コクランのリスクオブバイアスは 2016 年にVer.2

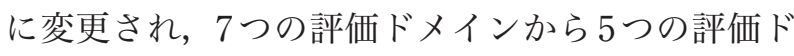
メイン (1) ランダム化のプロセスから生じるバイア ス, (2) 意図した介入からの逸脱によるバイアス, (3) 結果データの欠落によるバイアス, (4) 結果の測定に おけるバイアス，(5)報告された結果の選択における バイアスと全体評価ドメインに変更された(表1). より疫学的に精緻になるように，シグナリング質問 を使用し正確性を向上させ評価者間の不一致を少な くする目的があった．各ドメインのシグナリングク エスションに対して(1)Yes；Y, (2) Probably yes ; PY, (3) Probably no ; PN, (4) No ; N, (5) No information; NIで答え, 各ドメインリスクに対して, 低リスクオブバイアス (low risk of bias), やや疑わ しい(some concerns), 高リスクオブバイアス (high

*和歌山リハビリテーション専門職大学

(コクランジャパン学術理事)
著者連絡先 田中 優

帛 640-8222 和歌山県和歌山市湊本町 3-1 学校法人響和会

和歌山リハビリテーション専門職大学 
1. 質問の設定

2. 適格基準の計画

3. 方法の計画

4. 研究の検索

5. 適格基準の適用

6. デー夕収集

7. 研究のバイアスリスクの評価(リスクオプハイイアスによる適格論文の評価)

8. 結果の分析および提示

9. 結果の解釉と結論の導出

レビューの出版

10.レビューの改善とアップデート

アッブデートの出版

図1 コクラン系統的レビューのプロセス

〔文献1)より引用・改変〕

表1 コクランリスクオブバイアスのドメインの比較

\begin{tabular}{|c|c|}
\hline RoB1.0 & RoB2.0 \\
\hline ランダム割付の作成(選択バイアス) & \multirow{2}{*}{$\begin{array}{l}\text { ランダム化のプロセスで生じる } \\
\text { バイアス }\end{array}$} \\
\hline 割付の陰蔵化 (選択バイアス) & \\
\hline $\begin{array}{l}\text { 参加者と評価者のマスキング } \\
\text { (実行バイアス) }\end{array}$ & 意図した介入からのバイアス \\
\hline $\begin{array}{l}\text { 不完全なアウトカムデータ } \\
\text { (減少バイアス) }\end{array}$ & 意図した介入からの逸脱によるバイアス \\
\hline アウトカム評価のマスキング & 欠損アウトカムによるバイアス \\
\hline 選択的報告 & 報告された結果の選択によるバイアス \\
\hline その他のバイアス & （該当なし） \\
\hline 該当なし & 全体のバイアス \\
\hline
\end{tabular}

risk of bias)の 3 段階の評価をし，全体のバイアス の評価を作成するようになっている。

\section{III 具体的な手順}

5つのドメインごとのバイアスのリスクを評価 し，その結果で全体のバイアスのリスクを評価でき るようにリスクオブバイアス 2.0 は作られている. 5 つのドメインはシグナリング質問に答えるアルゴリ ズムに従って決定されていく。

(1)ランダム化のプロセスで生じるバイアス
ランダム化が成功すれば，介入群の割り付けに対 する既知または未知の予後因子(疾患の重症度や併 存疾患の存在などの転帰を予測する因子)の影響を 回避できる。このランダム化の過程がどの程度うま

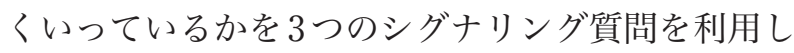
て判定する。

1.1 割付の順序はランダムか?

Y/PY は乱数表コンピューターによる乱数生成器 を使用してランダム系列を作った場合

N/PN は準ランダム-生年月日，受診日，ID また 


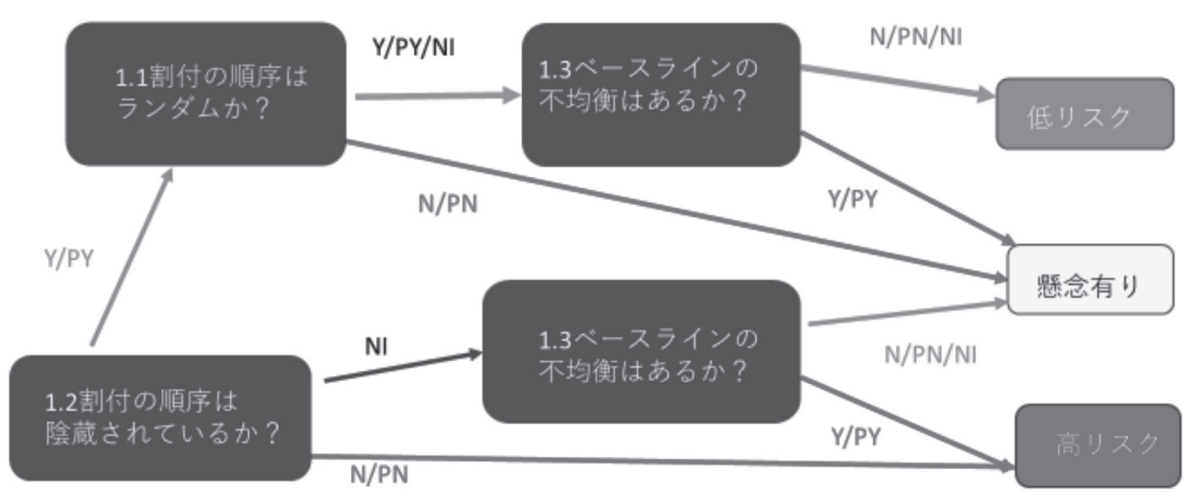

図2 ドメイン1のシグナリング質問によるリスクオブバイアスの決定の流れ

〔文献3)より引用・改変]

は記録番号の場合 非ランダムで医師または参加 者の選択，検査結果などを使用した場合

1.2 対象の募集と介入の割付は, 割付順序は隠蔽 されているか?

Y/PYは試験が遠隔または中央で実施された方法 のいずれかを用いて参加者に介入を割り振つた場 合 順に番号付けされる，密封された，不透明な 封筒を用いた場合

N/PN は試験責任者または試験参加者が，予定さ れている割付について知っていたと疑う理由があ る場合

1.3 ランダム化への問題を反映するようなベース ラインの不均衡はあるか?

Y/PYは両群のサイズ差が不自然に違う場合

$\mathrm{N} / \mathrm{PN}$ は両群で背景因子が均等になっている場 合

これらに答えることでフローチャートに従つて決 定される(図2).

(2)意図した介入からの逸脱によるバイアス

意図された介入から逸脱することによって生じる バイアスは，パフォーマンスバイアスと呼ばれるこ とがある。

7つのシグナリング質問があり Part 1 と Part 2 に 分かれている。

$<$ Part $1>$
2.1 患者は自身がどちらの群に割り付けられたか 知っていたか?

$\mathrm{Y} / \mathrm{PY}$ は参加者が割り当てられた介入を知ってい る場合，健康関連行動は介入群間で異なる可能性 が高い。いずれかの介入に特異的であることがわ かっている副作用または毒性を経験した参加者 N/PN は参加者を盲検化することは，最も一般的 にはプラセボまたは偽の介入を用いて，このよう な差を予防しうる

2.2 評価者は, 患者がどちらの群に割り付けられ たかを知っていたか？

Y/PY は介護者や介入者が割付を知っていると偏 りが生じることがある。N/PNはプラセボ対照か つブラインドされている

2.32 .1 または2.2で $\mathrm{Y}, \mathrm{PY}, \mathrm{NI}$ の場合，意図した 介入からの逸脱はあるか？

Y/PYは治療者が新たな治療法を良いと信じてい る背景が “明確”にある。N/PN は介入群に割り 付けられた患者が副作用のため治療を中断してい る場合などである

2.42 .3 で $\mathrm{Y} / \mathrm{PY}$ の場合，その逸脱はグループ間で バランスが取れているか?

試験実施計画書と矛盾し，試験の状況から生じた 割り付けられた介入からの変更は，結果に影響す る場合は介入効果の推定值に影響するが，そうで 


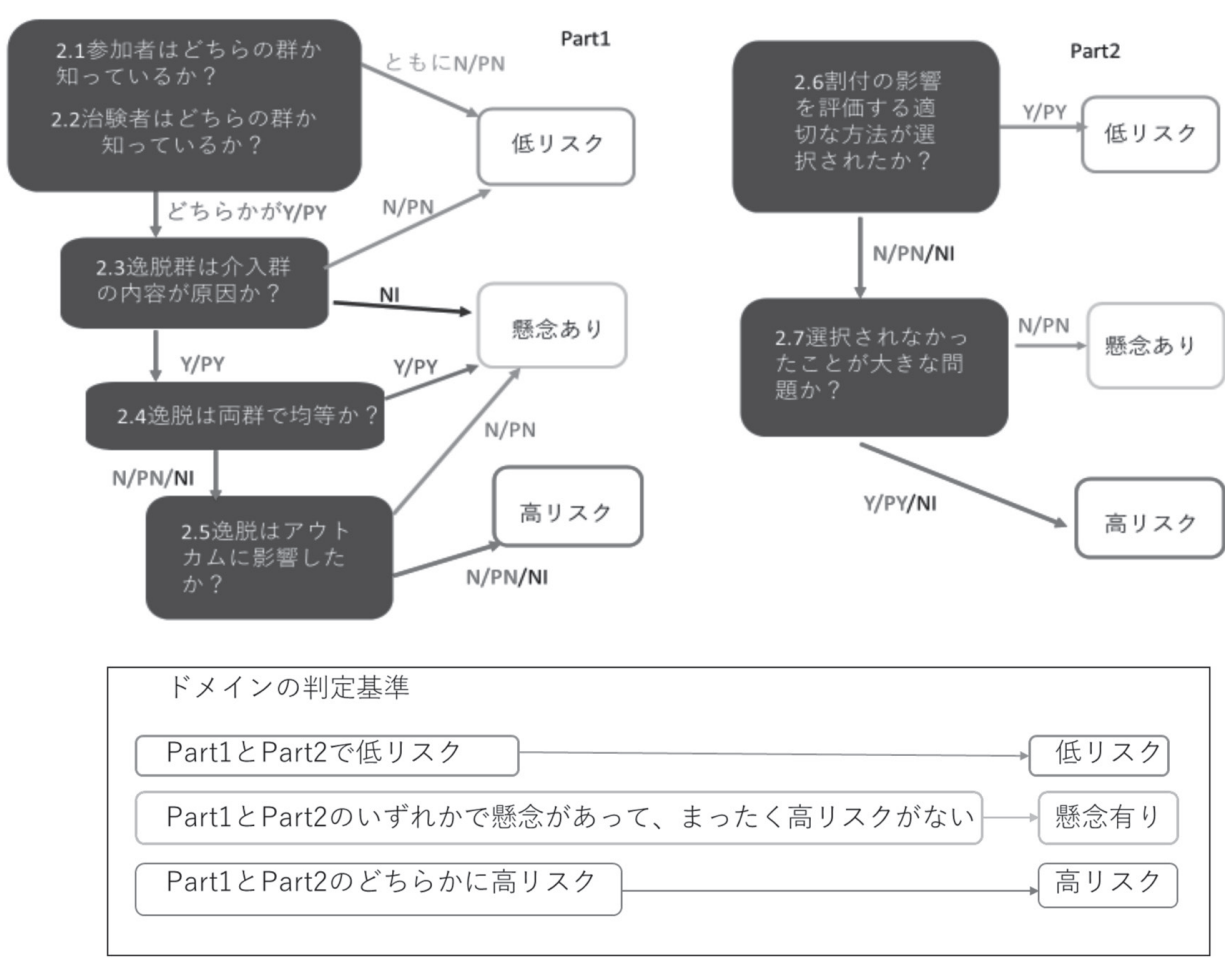

図 3 ドメイン2のシグナリング質問によるリスクオブバイアスの決定の流れ

〔文献3)上り引用・改変〕

なければ影響しない

2.52 .4 でN/PN/NI の場合, その逸脱はアウトカ ムに影響していると考えられるか？

試験プロトコルと矛盾し, 試験の状況から生じた 割り付けられた介入からの変更は，介入群間でバ ランスが取れていない場合, 介入効果の推定值に 影響を及ぼす可能性が高い

$<$ Part $2>$

2.6 介入を遵守した際の効果を推定する適切な解 析が行われたか?

Y/PYはITT解析, 修正ITT解析 N/PNは perprotocol解析, as treated 解析の場合

2.72 .6 でN/PN/NI の場合, 解析が上手くいかな かったため, 研究の結果に深刻な影響を与えた可能 性はあるか？

誤つた介入群で解析された参加者の数, または解 析から除外された参加者の数が，結果に実質的な
影響を及ぼすのに十分であったかどうかを検討す る

Part 1 と Part 2 の両方を見てドメイン 2 のリスク を判断する過程で複雑である(図3).

(3)欠損アウトカムによるバイアス

結果の測定值の欠落は，例えば，研究期間中の脱 落によって, 介入効果の推定值に偏りが生じること がある。

4つのシグナリング質問を利用して判定する.

3.1 ランダム化された参加者のアウトカムデータ はすべて，またはほとんどすべて利用可能か？

Y/PYは全員かほぼ全員のデータが使用できる場 合. N/PNは連続変数については欠損アウトカム が全体の $5 \%$ 以上

3.23 .1 でN/PN/NI の場合, 結果は欠損データに よって影響されていないか？

Y/PYはバイアスを修正する解析がされている場 


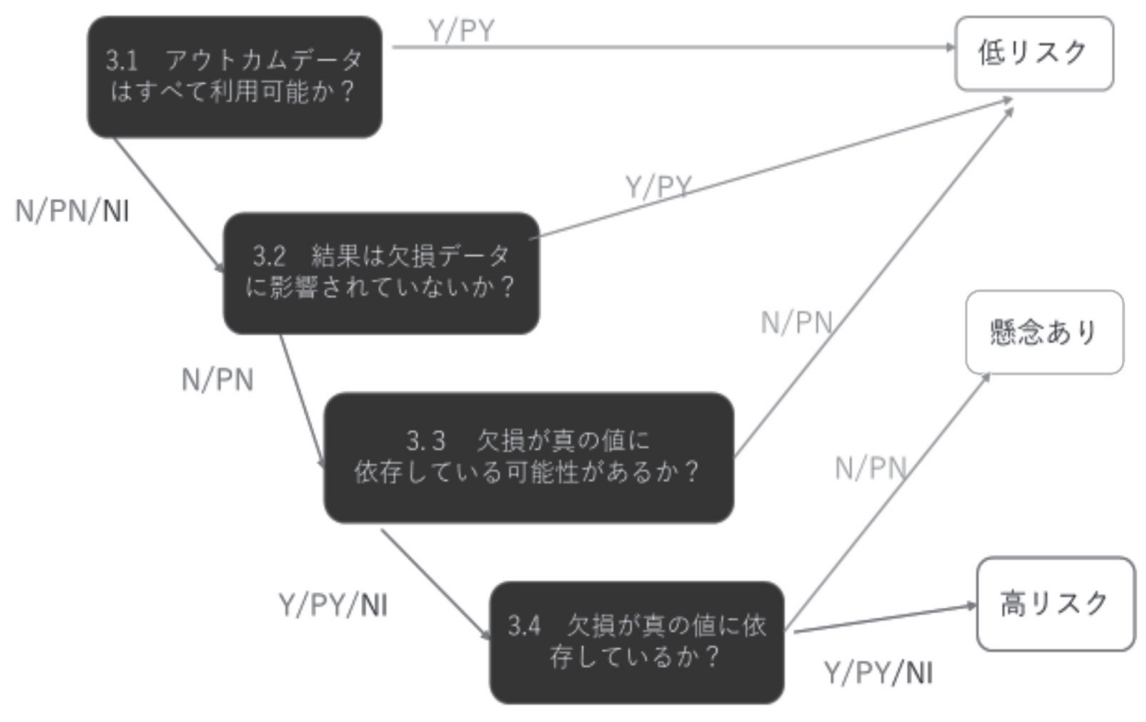

図4 ドメイン3のシグナリング質問によるリスクオブバイアスの決定の流れ

〔文献3)上り引用・改変〕

合など。N/PNは何も修正が加えられていない場 合

3.33 .2 でN/PN/NI の場合, 欠損が真の值に依存

している可能性はあるか？

Y/PYは追跡不能または試験からの脱落が参加者 の健康状態に関連している可能性がある場合，転 帰の欠落はその真の值に影響された可能性があ る。 N/PNは例えば, 測定装置の故障や日常的な データ収集の中断

3.43 .3 でN/PN/NI の場合, 欠損が真の值に依存 していると考えられるか？

Y/PYは副作用や取り下げによる欠測による偏 り。N/PNはその分析が, 結果のミッシングネス とその真の価值との関係を説明する可能性のある 参加者の特性を考慮しているとき

これらに答えることでフローチャートに従って決 定される(図4)。

(4)結果の測定におけるバイアス

結果の測定值の欠落は, 例えば, 研究期間中の被 検者の脱落によって, 介入効果の推定值に偏りが生 じることがある５つのシグナリング質問を利用し
て判定する.

4.1 アウトカムを測定する方法が不適切か？

N/PNは妥当な器機や測定法ではかられていると き

Y/PY は糖尿病検査で，ある血糖の濃度では妥当 でない器機を使用しているとき

4.2 アウトカムを測定する方法がグループ間で異 なるか?

N/PN はすべての群で同じ測定が行われている場 合. Y/PYは介入で負荷的にアウトカムを測定し たりばらつきがあると診断的探索バイアスが生じ る

4.34 .2 でN/PN/NI の場合，アウトカム評価者は 患者が受けた介入を知っていたか？

N/PNは，アウトカム評価者が盲検化されていれ ばNo

4.4 4.3で $\mathrm{Y} / \mathrm{PY} / \mathrm{NI}$ の場合, 介入を知っていたこ とが，評価に影響した可能性はあるか？

N/PN は死亡や大きな合併症であれば可能性はな い. Y/PYは痛みなど患者立脚型アウトカムは影 響を受ける 


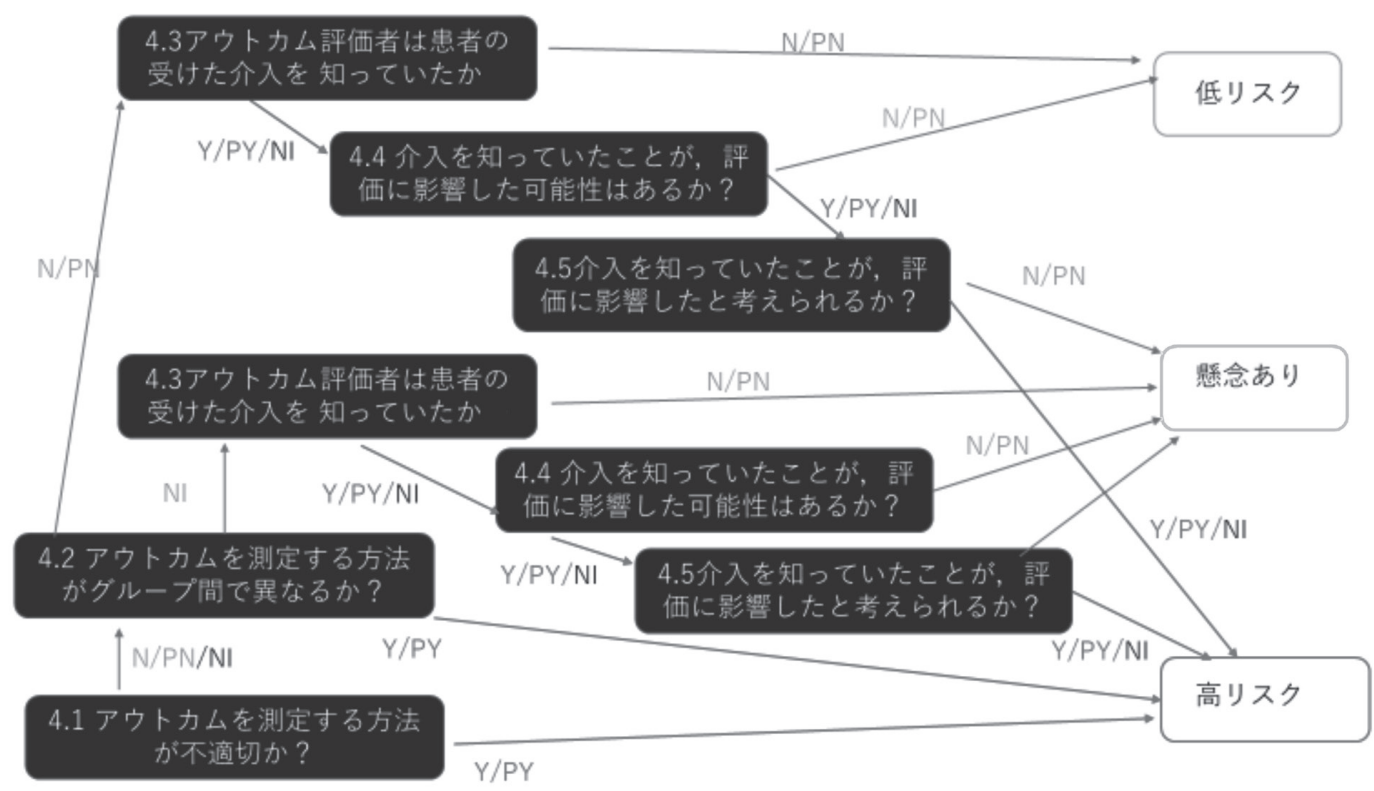

図 5 ドメイン4のシグナリング質問によるリスクオブバイアスの決定の流れ

〔文献3)ょり引用・改変〕

4.54 .4 でY/PY/NI の場合，介入を知っていたこ とが，評価に影響したと考えられるか？

$\mathrm{Y} / \mathrm{PY}$ は効果が強い介入ということを知っている 場合など，アウトカムに及ぼす影響が強くなる これらに答えることでフローチャートに従つて決 定される(図5)。

(5)報告された結果の選択によるバイアス

このドメインは，報告された結果が選択されるた めに生じるバイアスに対処する。このドメインは, 論文を読み解く際には特に重要である. 有意差の出 たアウトカムや，自分たちの予想に沿うアウトカム のみを報告したときに生じるバイアスで，選択的報 告バイアス selective reporting biasとも呼ばれる. このバイアスを疑うためには，まずプロトコールの 事前登録やプロトコール論文があるかを調べる。

3つのシグナリング質問を利用して判定する.

5.1 事前にプロトコールで決められたアウトカム

と，論文のアウトカムと一致しているか？

Y/PYは事前に定められた解析計画どおりに解析 されている場合。N/PNは事前に計画されていた
解析計画と違った分析がされている場合 5.2 アウトカムの中で, 複数のアウトカム測定が 行われているか?

Y/PYは分析の意図が利用できないか，分析の意 図が評価を可能にするほど詳細に報告されておら ず，結果の領域を測定する方法が複数ある場合. N/PNはアウトカムドメインを測定する方法は 1 つしかない.したがって，複数のメジャーから選 択する機会はない場合

5.3 データの解析に複数の方法が用いられている か?

Y/PY 例えば，実験的介入が有益であることを 示すことに先入観や既得権を持つ試験者は実験的 介入に有利な分析を選択的に報告する傾向がある かもしれない. N/PN アウトカムの測定値を分 析する方法は 1 つしかない場合

これらに答えることでフローチャートに従って決 定される(図6).

(6)全体的評価

判定基準は以下のようである。 


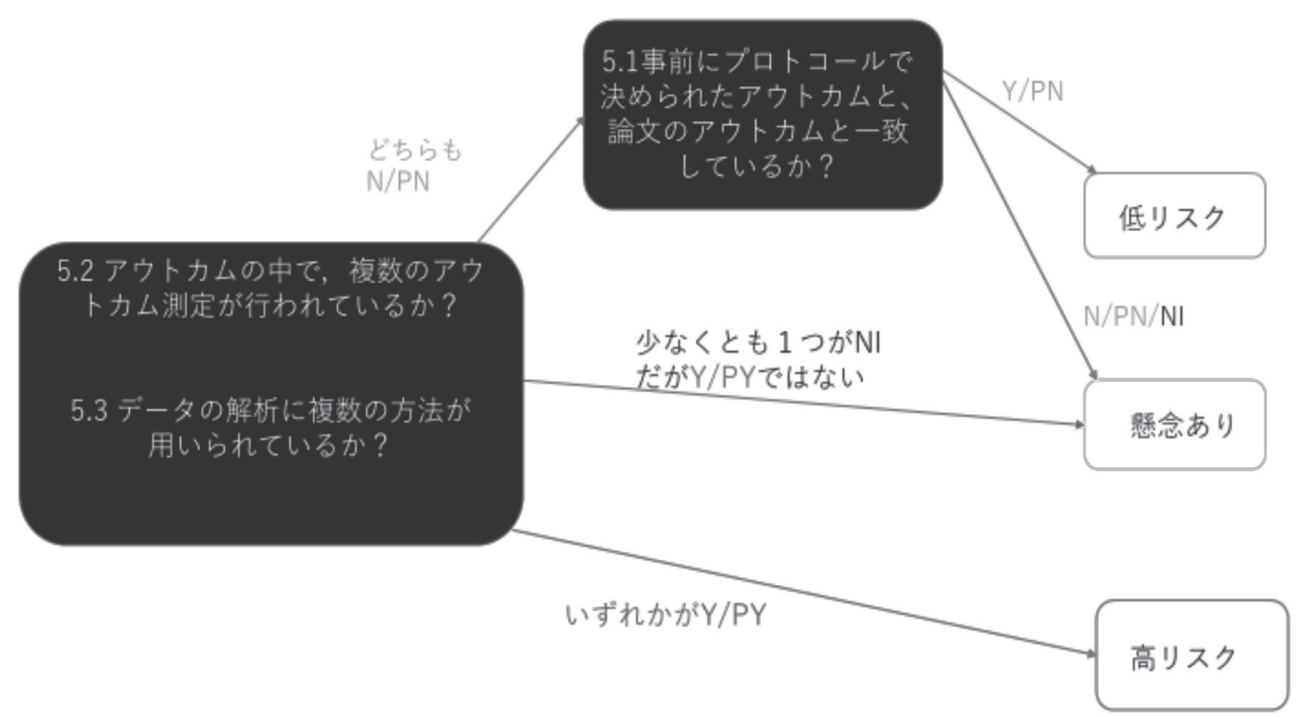

図6 ドメイン5のシグナリング質問によるリスクオブバイアスの決定の流れ

〔文献3)上り引用・改変〕

低い risk of bias(low risk of bias) : すべてのドメ インで，低リスク

いくらかの懸念(some concerns) : 少なくとも 1 つのドメインでいくらかの懸念があったがどこの ドメインにも高い risk of bias(high risk of bias) はなかった場合

高い risk of bias(high risk of bias)：少なくとも 1つのドメインで, 高い risk of bias があった, あるいは，複数のドメインでいくらかの懸念があ り，それが結果の信頼性を損ねた場合

\section{まとめ}

コクランリスクオブバイアスは有用ではあるが,
実際に実行するのはやや難しく普及に困難が伴う可 能性があり，目的としていた研究者間の一致なども 高くないという報告もある ${ }^{4)}$.

\section{参考文献}

1) 〈https://training.cochrane.org/handbook/current $\rangle$

2）志賀俊哉, 田中優：用心深く論文を読もう一何に注意 すべきか？臨床麻酔 $44: 1607-1615,2020$

3) 〈https://www.bristol.ac.uk/population-health-sciences/ centres/cresyda/barr/riskofbias/>

4) Minozzi S, Cinquini M, Gianola S, et al. : The revised Cochrane risk of bias tool for randomized trials $(\mathrm{RoB}$ 2 ) showed low interrater reliability and challenges in its application. J Clin Epidemiol $126: 37-44,2020$ 


\title{
About Cochrane Risk of Bias 2.0
}

\author{
Yuu TANAKA \\ Wakayama Professional University of Rehabilitation
}

Cochrane risk of bias has been widely used to assess bias in randomized controlled trials. The revised version of Cochrane Risk Bias 2.0 (RoB 2.0) was published in 2018. There are five domains : 1) bias resulting from the randomization process ;2) bias due to deviation from intended intervention;3) bias due to lack of outcome data ; 4) bias in measurement of results ; and 5) bias in the selection of reported results. The inclusion of signalling questions within each region of the domain is an important feature of RoB2 that aims to elicit information relevant to the risk assessment of bias. It can also determine the overall risk of bias.

Key Words : Cochrane risk of bias 2.0, Signalling question, Domain

The Journal of Japan Society for Clinical Anesthesia Vol.41 No.7, 2021 